\title{
Quantification of Leishmania infantum DNA in the bone marrow, lymph node and spleen of dogs
}

\author{
Quantificação de DNA de Leishmania infantum em medula óssea, linfonodo e baço de cães \\ Rafael Antonio Nascimento Ramos ${ }^{1,2 *}$; Carlos Alberto do Nascimento Ramos ${ }^{3}$; Edna Michelly de Sá Santos ${ }^{2}$; \\ Flábio Ribeiro de Araújo ${ }^{3}$; Gílcia Aparecida de Carvalho ${ }^{4}$; Maria Aparecida da Gloria Faustino²; Leucio Câmara Alves ${ }^{2}$ \\ ${ }^{1}$ Dipartimento di Medicina Veterinaria, Università degli Studi di Bari - UNIBA, Valenzano, Bari, Italy \\ ${ }^{2}$ Laboratório de Doenças Parasitárias dos Animais Domésticos, Universidade Federal Rural de Pernambuco - UFRPE, Recife, PE, \\ Brasil \\ ${ }^{3}$ Laboratório de Imunologia, Embrapa Gado de Corte, Campo Grande, MS, Brasil \\ ${ }^{4}$ Unidade Acadêmica de Garanhuns, Universidade Federal Rural de Pernambuco - UFRPE, Garanhuns, PE, Brasil
}

Received February 3, 2013

Accepted May 22, 2013

\begin{abstract}
The aim of the present study was to quantify the parasite load of Leishmania infantum in dogs using real-time PCR (qPCR). Bone marrow, lymph node and spleen samples were taken from 24 dogs serologically positive for L. infantum that had been put down by the official epidemiological surveillance service. According to the clinical signs the dogs were classified as asymptomatic or symptomatic. After DNA extraction, the samples were subjected to qPCR to detect and quantify L. infantum DNA. Out of the 24 dogs, $12.5 \%$ (3/24) were classified as asymptomatic and 87.5\% (21/24) as symptomatic. Real-time PCR detected L. infantum DNA in all the animals, in at least one biological sample. In particular, 100\% of bone marrow and lymph node scored positive, whereas in spleen, the presence of DNA was detected in $95.9 \%$ (23/24). In addition, out of 24 animals, 15 were microscopically positive to amastigote forms of L. infantum in bone marrow. No statistical significant difference was found in the overall mean quantity of DNA among the different biological samples $(\mathrm{P}=0.518$ ). Considering each organ separately, there was $100 \%$ positivity in bone marrow and lymph nodes, while among the spleen samples, 95.9\% (23/24) were positive. Regarding the different clinical groups, the overall mean parasite load varied significantly $(P=0.022)$. According to the results obtained, it was not possible determine which biological sample was most suitable tissue for the diagnosis, based only on the parasite load. Therefore, other characteristics such as convenience and easily of obtaining samples should be taken into consideration.
\end{abstract}

Keywords: Leishmania, molecular, diagnosis, parasite load, dogs.

\section{Resumo}

O objetivo do presente estudo foi quantificar a carga parasitária de Leishmania infantum em cães pela técnica de PCR em tempo-real (qPCR). Amostras de medula óssea, linfonodo e baço foram obtidos de 24 cães sorologicamente positivos para $L$. infantum que foram submetidos à eutanásia pelo serviço de vigilância oficial. Segundo os sinais clínicos, os animais foram classificados em assintomáticos ou sintomáticos. Após extração de DNA, as amostras foram submetidas à qPCR para detecção e quantificação de DNA de L. infantum. Dos 24 cães, 12,5\% (3/24) foram classificados como assintomáticos e 87,5\% (21/24) como sintomáticos. A PCR em tempo real detectou DNA de L. infantum em $100 \%$ dos animais, em pelo menos uma amostra biológica. Considerando cada órgáo isoladamente, foi observada uma positividade de $100 \%$ em medula óssea e linfonodo, já nas amostras de baço 95,9\% (23/24) foram positivas. Não foi observada diferença estatística entre a quantidade média geral de DNA entre as diferentes amostras biológicas $(\mathrm{P}=0,518)$. Considerando os diferentes grupos clínicos, a carga parasitária média geral variou significantemente $(\mathrm{P}=0,022)$. De acordo com os resultados obtidos não foi possível eleger a mais apropriada amostra biológica para o diagnóstico, baseado apenas na carga parasitária. Portanto, outras características como a conveniência e a facilidade de obtenção da amostra devem ser consideradas.

Palavras-chave: Leishmania, molecular, diagnóstico, carga parasitária, cães.

\footnotetext{
*Corresponding author: Rafael Antonio Nascimento Ramos

Laboratório de Doenças Parasitárias dos Animais Domésticos, Universidade

Federal Rural de Pernambuco - UFRPE, Av. Dom Manoel de Medeiros, s/n,

Dois Irmāos, CEP 52171-900, Recife, PE, Brazil

e-mail: rafaelanramos10@yahoo.com.br
} 


\section{Introduction}

Visceral leishmaniasis (VL) caused by Leishmania infantum (Kinetoplastida, Trypanosomatidae) is considered an important vector-borne disease, as well as a serious threat to public health (DANTAS-TORRES et al., 2012). Although several wild species can potentially be infected (LUPPI et al., 2008), domestic dogs are considered the main reservoir for $L$. infantum, particularly within urban areas. In these animals, the canine visceral leishmaniasis (CVL) displays a multifaceted clinical picture, varying from asymptomatic to nonspecific signs (e.g. skin lesions, lymphadenomegaly, weight loss, splenomegaly and/or ocular lesions) (BANETH et al., 2008), thus impairing prompt diagnosis.

Several diagnostic tools have been applied to detect this infection in dogs, including parasitological, serological (MOREIRA et al., 2007) and molecular techniques (ROLÃO et al., 2004). In Brazil, the official diagnosis is based on serological tests, i.e. an enzymelinked immunosorbent assay (ELISA) followed by an indirect immunofluorescent antibody test (IFAT $\geq 1: 40$ ) as a confirmatory test (FIGUEIREDO et al., 2010). However, these techniques present limitations, with results that are insufficient for a reliable diagnosis of CVL. Conversely, molecular methods have acquired considerable importance for diagnosing many diseases, including CVL. Real-time PCR (qPCR) has presented high sensitivity and specificity for diagnosing and monitoring parasite loads in different biological samples (MARY et al., 2004; TUPPERWAR et al., 2008; RAMOS et al., 2012). However, based on the parasite load, it is still unclear which biological sample should be preferred in order to make a correct diagnosis (IKONOMOPOULOS et al., 2003; BARROUIN-MELO et al., 2006; SOLCÀ et al., 2012).

Therefore, the aim of the present study was to evaluate which of the biological samples routinely collected (i.e. bone marrow, lymph nodes and spleen) for diagnosing CVL should be considered the most suitable for molecular detection of $L$. infantum, based on the parasite load quantified by a qPCR protocol.

\section{Materials and Methods}

\section{Ethical issues}

According to the Brazilian Ministry of Health, animals infected with $L$. infantum should be put down through the Visceral Leishmaniasis Surveillance and Control Program. In this study, all the animals were seroreactive for $L$. infantum in both serological tests (ELISA and IFAT $\geq 1: 40$ ). In addition, 15 animals were bone marrow smear positive. The animals were put down by the official epidemiological surveillance service of the city of Petrolina (state of Pernambuco, Brazil), in accordance with the recommendations of the Brazilian Federal Council of Veterinary Medicine. The present study received approval from the Ethics Committee for Animal Experimentation of the Federal Rural University of Pernambuco (protocol ECAE: 23082.015004/2011).

\section{Animals}

A total of 72 samples were obtained from 24 dogs that were serologically positive for $L$. infantum. The samples were acquired from the Zoonotic Disease Control Center of the city of Petrolina (Pernambuco, Brazil). The serological diagnosis was made using ELISA S7" (Biogene Ind. e Com. Ltda., Recife, Pernambuco, Brazil), in conformity with the manufacturer's instructions. Moreover, the indirect fluorescent antibody test (IFAT $\geq 40$ ) was performed using the protocol described by Oliveira et al. (2008). According to the clinical signs of leishmaniasis, the dogs were classified as asymptomatic or symptomatic.

In addition, samples from three healthy dogs, from non endemic area, that were serologically (IFAT and ELISA) and bone marrow smear negative were used in this study.

\section{Sample acquisition}

Before the animals were put down, a bone marrow biopsy was performed directly from the manubrium of the sternum, and samples were placed in sterile tubes containing anticoagulant (heparin). In addition, bone marrow smears were prepared on glass slides, stained with Diff-Quick (Dade, Miami, Florida, USA) and examined under an optical microscope to determine whether amastigote forms of $L$. infantum were present. Each smear was examined for 10 minutes (100 microscopic fields) under a 100x oil immersion objective lens. After the animals had been put down, spleen fragments and popliteal lymph nodes were collected.

Because of the high degree of sensitivity inherent to qPCR, special care was taken to avoid cross-contamination during the sample collection procedure. All the materials used were separated individually for each animal and were decontaminated by means of UV radiation prior to each procedure. Since lymph nodes are small organs and more susceptible to contamination during collection, they were retrieved intact, after a smaller fragment was obtained under controlled conditions in the laboratory. Bone marrow aspirates and lymph nodes were also collected from the control negative dogs and subjected to qPCR.

\section{Molecular diagnosis}

\section{DNA extraction}

Genomic DNA from the bone marrow, lymph node and spleen tissues were extracted using the QIAamp DNA Blood and Tissue kit (Qiagen Inc., Valencia, USA). The extractions were performed on $200 \mu \mathrm{L}$ of bone marrow, $25 \mathrm{mg}$ of lymph node and $10 \mathrm{mg}$ of spleen tissue (manufacturer's instructions). After extraction, DNA concentrations were determined by means of spectrophotometry in the GeneQuant RNA/DNA calculator (GE Healthcare BioSciences Corp.; New Jersey, USA). The integrity of the DNA samples was evaluated by means of electrophoresis on $0.8 \%$ agarose gel, stained with ethidium bromide $(0.5 \mu \mathrm{g} / \mathrm{ml})$. When necessary, the DNA samples were adjusted to a concentration of 
$100 \eta \mathrm{g} / \mu \mathrm{l}$. All the procedures were performed using micropipette barrier tips to prevent contamination.

\section{Real-time PCR}

The $\mathrm{qPCR}$ reactions were performed using the primers LEISH-1 (5'-AACTTTTCTGGTCCTCCGGGTAG-3') and LEISH-2 (5'-ACCCCCAGTTTCCCGCC-3') and the probe (FAM- 5'-AAAAATGGGTGCAGAAAT-3'- NFQ -MGB), based on Francino et al. (2006). The amplification protocol consisted of initial denaturation at $95^{\circ} \mathrm{C}$ for $3 \mathrm{~min}$, followed by 42 cycles of denaturation $\left(95^{\circ} \mathrm{C}\right.$ for 10 seconds) and annealing-extension ( $60{ }^{\circ} \mathrm{C}$ for 30 seconds). All assays were carried out in triplicate, with each battery containing a negative control (DNA from a serologically negative dog) and a positive control (DNA from an in vitro culture of $L$. infantum). Parasites were quantified as absolute counts. A standard curve was determined, with dilutions of $L$. infantum DNA from an in vitro culture containing approximately $5.6 \times 10^{6}$ parasites $/ \mathrm{ml}$. Taking the extraction efficiency to be $100 \%$, eight serial dilutions of the DNA stock were established using nuclease-free water. Four points were used for the curve: $0.01,1$, 1000 and 1,000,000 parasites $/ \mathrm{ml}$. To prevent cross-contamination, all procedures were carried out in an appropriate environment and filter tips were routinely used in all DNA extraction steps as well as during qPCR. Moreover, all materials and the laminar flow hood were decontaminated by means of UV radiation before and after each procedure.

\section{Statistical analysis}

The data were subjected to statistical analysis using the Kruskal-Wallis test. Differences were considered to be statistically significant when $\mathrm{p}<0.05$.

\section{Results}

Out of the 24 dogs analyzed in the present study, $12.5 \%$ (3/24) were classified as asymptomatic and $87.5 \%(21 / 24)$ as symptomatic. According to the clinical evaluation, the clinical signs most frequently observed were dermatopathy, weight loss, onychogryphosis and ophthalmopathy.

The qPCR detected L. infantum DNA in all the animals, in at least one biological sample. In particular, $100 \%$ of the bone marrow and lymph node samples were found to be positive, whereas in the spleen samples, presence of DNA was detected in $95.9 \%$ (23/24). Out of the 24 animals, 15 were positive for amastigote forms of L. infantum in bone marrow (Table 1). No statistically significant difference in the overall mean quantity of DNA was found among the different biological samples $(\mathrm{P}=0.518)$. Conversely,

Table 1. Clinical classification, parasite load of each biological sample and results of the bone marrow cytology from dogs naturally infected by Leishmania chagasi.

\begin{tabular}{|c|c|c|c|c|c|}
\hline \multirow{2}{*}{ Animal } & \multirow{2}{*}{ Clinical classification } & \multicolumn{3}{|c|}{ qPCR* } & \multirow{2}{*}{ Bone marrow smears } \\
\hline & & Bone marrow & Lymph node & Spleen & \\
\hline 01 & Asymptomatic & 0.045 & 0.215 & 0.089 & Negative \\
\hline 02 & Asymptomatic & 0.337 & 76.321 & 1.273 & Positive \\
\hline 03 & Asymptomatic & 0.267 & 0.007 & 0.066 & Positive \\
\hline 04 & Symptomatic & 0.015 & 2.908 & 0.228 & Negative \\
\hline 05 & Symptomatic & 0.029 & 0.001 & 0.053 & Negative \\
\hline 06 & Symptomatic & 0.037 & 0.526 & 0.178 & Positive \\
\hline 07 & Symptomatic & $2,539.455$ & $4,745.122$ & 287.61 & Positive \\
\hline 08 & Symptomatic & 0.051 & 0.015 & 0.092 & Negative \\
\hline 09 & Symptomatic & $34,940,375.0$ & $1,813,558.0$ & $1,028,954.75$ & Positive \\
\hline 10 & Symptomatic & 0.156 & 28.911 & 6.663 & Negative \\
\hline 11 & Symptomatic & 0.035 & 5.984 & 7.427 & Negative \\
\hline 12 & Symptomatic & 0.789 & 3.225 & 0.391 & Positive \\
\hline 13 & Symptomatic & 0.155 & 14.411 & 0 & Positive \\
\hline 14 & Symptomatic & 0.023 & 7.559 & 0.188 & Negative \\
\hline 15 & Symptomatic & 0.352 & 1.687 & 6.518 & Negative \\
\hline 16 & Symptomatic & $127,467.672$ & $4,290,952.0$ & $6,705,212.5$ & Positive \\
\hline 17 & Symptomatic & $14,805.015$ & $152,398.609$ & $281,605.406$ & Positive \\
\hline 18 & Symptomatic & $53,881.105$ & $937,240.438$ & $511,766.031$ & Negative \\
\hline 19 & Symptomatic & 0.044 & 0.149 & 0.087 & Positive \\
\hline 20 & Symptomatic & 14.778 & 1.388 & 2.042 & Positive \\
\hline 21 & Symptomatic & 38.465 & $112,590.148$ & $8,844.795$ & Positive \\
\hline 22 & Symptomatic & $2,382.702$ & $134,308.328$ & $11,697.836$ & Positive \\
\hline 23 & Symptomatic & $12,250.853$ & $204,420.672$ & $473,047.281$ & Positive \\
\hline 24 & Symptomatic & $1,159.568$ & 208.293 & $83,550.594$ & Positive \\
\hline
\end{tabular}

*Results expressed as number of parasite/mL of DNA. 
considering the different clinical groups, the overall mean parasite loads differed significantly $(\mathrm{P}=0.022)$. Animals that were negative in bone marrow smears presented parasite loads lower than 0.4 parasite/ml, except sample 18, which curiously presented a high parasite load in the bone marrow (Table 1).

All the samples (bone marrow and lymph node) from the negative control animals were also qPCR-negative.

\section{Discussion}

In this study, a comparison between the mean quantities of $L$. infantum DNA detected by means of qPCR in different biological samples was carried out. The results reported here indicate that the overall mean load of $L$. infantum DNA did not differ significantly among bone marrow, lymph node and spleen samples collected from the dogs, but differed between the clinical groups (i.e. asymptomatic and symptomatic).

The tropism of L. infantum caused by lymphoid organs (e.g. bone marrow, lymph nodes and spleen) makes them important for detecting this protozoon. Different studies have demonstrated high positive rates of $L$. infantum detection in lymph nodes (IKONOMOPOULOS et al., 2003), spleen (SOLCÀ et al., 2012) and bone marrow (FERREIRA et al., 2012) using molecular biology tests. Some of them have suggested that lymph nodes are the best biological samples for molecular diagnosis of $L$. infantum (IKONOMOPOULOS et al., 2003; RAMOS et al., 2012). Nonetheless, few studies on parasite load quantification have been conducted, even though such information is extremely important for correctly choosing the sample to be used. It has been demonstrated that popliteal lymph node aspirate and bone marrow present higher parasitic loads than blood samples or buffy coat (FRANCINO et al., 2006; QUARESMA et al., 2009; MANNA et al., 2009). In the present study, this difference among the parasite loads of the different biological samples was not detected statistically. This finding may be explained by the characteristics of the organs utilized, given that all of them were lymphoid organs, unlike in previous studies. In bone marrow samples from dogs that were cytologically positive, a high parasite load was detected (samples 07, 09, 16, 17, 20, 21, 22, 23 and 24). This finding showed that there was a direct correlation between positive parasitological tests and high loads of L. infantum DNA (QUARESMA et al., 2009). Curiously, one cytologically negative bone marrow sample (18) displayed a high parasite load. Considering the mean quantity of L. infantum DNA in this sample, this was an unusual result. However, it is important highlight that parasite detection by means of direct cytological examination presents low sensitivity (MOREIRA et al., 2007) and, although minimal, the possibility of operational error in this cytological analysis cannot be completely ruled out.

Regarding the parasite loads in the different clinical evaluations, the data showed that there was a positive correlation $(\mathrm{P}=0.022)$ between symptomatic dogs and parasite loads. Previous studies detected higher parasite loads in the lymph nodes of symptomatic dogs than in asymptomatic dogs, and similar findings were obtained through blood samples (i.e. a higher quantity was recorded in symptomatic dogs than in asymptomatic dogs) (MANNA et al.,
2009). However, there is no unanimity regarding this positive correlation observed between symptomatic animals and high parasitic loads. Some studies have suggested that CVL can begin either as an asymptomatic condition with generalized parasite dissemination, or as severe clinical symptoms with a low parasite load (QUINNELL et al., 2003; ALVAR et al., 2004).

Several parameters should be considered in choosing the sample to be used. The clinical procedures used to obtain samples may be traumatic and painful for animals. It is known that collecting bone marrow is painful and invasive (i.e. special care is needed to avoid infection), thus making anesthesia or sedation of the animal necessary. Similarly, the procedure to collect spleen aspirates is risky, compared with other biological samples, considering that there is a constant possibility of inducing hemorrhage (LÉVEILLÉ et al., 1993). Therefore, these limitations make this procedure particularly unsuitable for large-scale collections (i.e. places with high densities of animals, such as canine shelters or kennels). In turn, obtaining lymph node aspirates not only is easier from a practical point of view but also demonstrates the greater viability of this biological sample over bone marrow and spleen samples. In addition, this biological sample (lymph node) has been demonstrated to be useful for detecting the protozoon, independently of the animal's clinical status (RAMOS et al., 2012).

Finally, based on the results relating to DNA parasite loads, it was not possible to indicate the most suitable biological sample for diagnosing CVL. However, the ease of collecting the sample should be taken into consideration. Thus, in view of the practicality of obtaining lymph node aspirates, these samples can be suggested to be a suitable source for making diagnoses of CVL.

\section{Acknowledgements}

The authors thank the Science and Technology Support Foundation of the State of Pernambuco (Fundação de Amparo a Ciência e Tecnologia do Estado de Pernambuco, Facepe) and the Health Department of the State of Pernambuco for partially supporting this study.

\section{References}

Alvar J, Cañavate C, Molina R, Moreno J, Nieto J. Canine leishmaniasis. Adv Parasitol 2004; 57(1): 1-88. http://dx.doi.org/10.1016/S0065308X(04)57001-X

Barrouin-Melo SM, Larangeira DF, Andrade FA Fo, Trigo J, Juliāo FS, Franke CR, et al. Can spleen aspirations be safely used for the parasitological diagnosis of canine visceral leishmaniosis? A study on asymptomatic and polysymptomatic animals. Vet J 2006; 171(2): 331339. PMid:16490717. http://dx.doi.org/10.1016/j.tvjl.2004.11.010

Baneth G, Koutinas AF, Solano-Gallego L, Bordeau P, Ferrer L. Canine leishmaniosis - new concepts and insights on an expanding zoonosis: part one. Trends Parasitol 2008; 24(1): 324-330. PMid:18514028. http:// dx.doi.org/10.1016/j.pt.2008.04.001

Dantas-Torres F, Solano-Gallego L, Baneth G, Ribeiro VM, Paiva-Cavalcanti M, Otranto D. Canine leishmaniosis in the Old and New Worlds: unveiled similarities and differences. Trends 
Parasitol 2012; 28(12): 531-538. PMid:22995719. http://dx.doi. org/10.1016/j.pt.2012.08.007

Ferreira SA, Leite RS, Ituassu LT, Almeida GG, Souza DM, Fujiwara RT, et al. Canine skin and conjunctival swab samples for the detection and quantification of Leishmania infantum DNA in an endemic urban area in Brazil. PLoS Negl Trop Dis 2012; 6(4): e1596.

Figueiredo FB, Madeira MF, Nascimento LD, Abrantes TR, MoutaConfort E, Passos SR, et al. Canine visceral leishmaniasis: study of methods for the detection of $\mathrm{IgG}$ in serum and eluate samples. Rev Inst Med Trop S Paulo 2010; 52(4): 193-196. PMid:21748226. http://dx.doi. org/10.1590/S0036-46652010000400005

Francino O, Altet L, Sánchez-Robert E, Rodriguez A, Solano Gallego L, Alberola J, et al. Advantages of real-time PCR assay for diagnosis and monitoring of canine leishmaniosis. Vet Parasitol 2006; 137(3-4): 214221. PMid:16473467. http://dx.doi.org/10.1016/j.vetpar.2006.01.011

Ikonomopoulos J, Kokotas S, Gazouli M, Zavras A, Stoitsiou M, Gorgoulis VG. Molecular diagnosis of leishmaniosis in dogs. Comparative application of traditional diagnostic methods and the proposed assay on clinical samples. Vet Parasitol 2003; 113(2): 99-113. http://dx.doi. org/10.1016/S0304-4017(03)00061-X

Léveillé R, Partington BP, Biller DS, Miyabayashi T. Complications after ultrasound-guided biopsy of abdominal structures in dogs and cats:246 cases (1984-1991). J Am Vet Med Assoc 1993; 203(3): 413-415. PMid:8226218.

Luppi MM, Malta MC, Silva TM, Silva FL, Motta RO, Miranda I, et al. Visceral leishmaniasis in captive wild canids in Brazil. Vet Parasitol 2008; 155(1-2): 146-151. PMid:18556130. http://dx.doi. org/10.1016/j.vetpar.2008.04.024

Manna L, Reale S, Vitale F, Gravino AE. Evidence for a relationship between Leishmania load and clinical manifestations. Res Vet Sci 2009; 87(1):76-78. PMid:19178919. http://dx.doi.org/10.1016/j. rvsc.2008.12.009

Mary C, Faraut F, Lascombe L, Dumon H. Quantification of Leishmania infantum DNA by a real-time PCR assay with high sensitivity. J Clin Microbiol 2004; 42(11): 5249-5255. PMid: 15528722 PMCid:PMC525214. http://dx.doi.org/10.1128/JCM.42.11.52495255.2004
Moreira MAB, Luvizotto MCR, Garcia JF, Corbett CEP, Laurenti MD. Comparison of parasitological, immunological and molecular methods for the diagnosis of leishmaniasis in dogs with different clinical signs. Vet Parasitol 2007; 145(3-4): 245-252. PMid:17257764. http://dx.doi. org/10.1016/j.vetpar.2006.12.012

Oliveira TMS, Furuta PI, Carvalho D, Machado RZ. A study of crossreactivity in serum samples from dogs positive for Leishmania sp. Babesia canis and Ehrlichia canis in enzyme-linked immunosorbent assay and indirect fluorescent antibody test. Rev Bras Parasitol Vet 2008; 17(1): 7-11. PMid:18554433.

Quaresma PF, Murta SMF, Ferreira EC, Rocha-Lima ACVM, Xaviera AAP, Gontijo CMF. Molecular diagnosis of canine visceral leishmaniasis: Identification of Leishmania species by PCR-RFLP and quantification of parasite DNA by real-time PCR. Acta Trop 2009; 111(3): 289-294. PMid:19467216. http://dx.doi.org/10.1016/j.actatropica.2009.05.008

Quinnell RJ, Kennedy LJ, Barnes A, Courtenay O, Dye C, Garcez LM, et al. Susceptibility to visceral leishmaniasis in the domestic dog is associated with MHC class II polymorphism. Immunogenetics 2003; 55(1): 23-28. PMid:12715244.

Ramos RAN, Ramos CAN, Jusi MMG, Araújo FR, Machado RZ, Faustino MAG, et al. Polymerase chain reaction and real-time PCR for diagnosing of Leishmania infantum chagasi in dogs. Rev Bras Parasitol Vet 2012; 21(3): 192-195. PMid:23070425. http://dx.doi.org/10.1590/ S1984-29612012000300003

Rolão N, Cortes S, Rodrigues OR, Campino L. Quantification of Leishmania infantum parasites in tissue biopsies by real-time polymerase chain reaction and polymerase chain reaction-enzymelinked immunosorbent assay. J Parasitol; 2004; 90(5): 1150-1154. PMid:15562617. http://dx.doi.org/10.1645/GE-264R1

Solcà MS, Guedes CES, Nascimento EG, Oliveira GGS, Santos WLC, Fraga DBM, et al. Qualitative and quantitative polymerase chain reaction (PCR) for detection of Leishmania in spleen samples from naturally infected dogs. Vet Parasitol 2012; 184(2-4): 133-140. PMid:21917379. http://dx.doi.org/10.1016/j.vetpar.2011.08.026

Tupperwar N, Vineeth V, Rath S, Vaidya T. Development of a real-time polymerase chain reaction assay for the quantification of Leishmania species and the monitoring of systemic distribution of the pathogen. Diagn Microbiol Infect Dis 2008; 61(1): 23-30. PMid:18255247. http:// dx.doi.org/10.1016/j.diagmicrobio.2007.12.013 